\title{
Impacts of invasive alien plants on water quality, with particular emphasis on South Africa
}

\author{
J Chamier $^{1 *}$, K Schachtschneider $^{1}$, DC le Maitre ${ }^{1}$, PJ Ashton ${ }^{2}$ and BW van Wilgen ${ }^{3}$ \\ ${ }^{1}$ CSIR Natural Resources and the Environment, PO Box 320, Stellenbosch 7599, South Africa \\ ${ }^{2}$ CSIR Natural Resources and the Environment, PO Box 395, Pretoria 0001, South Africa \\ ${ }^{3}$ Centre for Invasion Biology, CSIR Natural Resources and the Environment, PO Box 320, Stellenbosch 7599, South Africa
}

\begin{abstract}
We review the current state of knowledge of quantified impacts of invasive alien plants on water quality, with a focus on South Africa. In South Africa, over 200 introduced plant species are regarded as invasive. Many of these species are particularly prominent in riparian ecosystems and their spread results in native species loss, increased biomass and fire intensity and consequent erosion, as well as decreased river flows. Research on the impact of invasive alien plants on water resources has historically focused on water quantity. However, although invasive alien plants also affect the quality of water, this aspect has not been well documented. Alien invasive plants increase evaporation rates, and reduce stream flow and dilution capacity. The biomass inputs of alien invasive plants, especially nitrogen fixers such as Acacia spp., alter nutrient cycles and can elevate nutrient concentrations in groundwater. Alien plant invasions alter the fire regimes in invaded areas by changing the size, distribution and plant chemistry of the biomass. More intense fires increase soil erosion and thereby decrease water quality. In contrast to riparian invasions, aquatic invasive plants have been more extensively studied in South Africa and their impacts on water quality have been relatively well monitored. Water quality in South Africa is rapidly deteriorating, and all factors that influence this deterioration need to be taken into account when formulating actions to address the problem. The changes in water quality brought about by alien plant invasions can exacerbate the already serious water quality problems.
\end{abstract}

Keywords: aquatic weeds, nutrient cycling, erosion, fire intensity, South Africa

\section{Introduction}

Invasive alien plants are a significant environmental problem in South Africa's terrestrial and freshwater ecosystems (Richardson et al., 1997). Alien trees and shrubs increase above-ground biomass and evapotranspiration and thereby decrease both surface water runoff and groundwater recharge (Görgens and Van Wilgen, 2004). The increased biomass and evapotranspiration rates associated with invasive alien plants arise because of their greater height, root depth and senescence, compared to the native species that they replace (Calder and Dye, 2001). The increased biomass that accompanies plant invasions also results in more intense fires that damage the vegetation and soil and lead to excessive erosion; in addition, invasive alien plants reduce the capacity of rangelands to support livestock and wildlife, and significantly reduce biodiversity (Richardson and Van Wilgen, 2004).

The reduction in surface water runoff as a result of current invasions was estimated to be $3300 \mathrm{Mm}^{3}$ (about $7 \%$ of the national total, Le Maitre et al., 2000), most of which is from the fynbos (shrubland) and grassland biomes (Van Wilgen et al., 2008). These areas are especially sensitive to invasions as most of South Africa's surface water originates from the Drakensberg mountain grasslands, and from the Cape mountains which are dominated by fynbos vegetation (Turpie et al., 2008). The Cape fynbos has been invaded by alien plants that have escaped from commercial plantations and woodlots on farms (i.e. Pinus, Acacia and Eucalyptus species), and

\footnotetext{
* To whom all correspondence should be addressed.

iil +2721888 2553; fax: +27 21888 2862;

e-mail: ichamier@csir.co.za

Received 10 October 2011; accepted in revised form 18 April 2012.
}

grasslands' ecological integrity has been compromised by poor land use management practices, which include overgrazing and burning regimes, and damming and reclamation of wetlands (Turpie et al., 2008).

The potential water reductions would be more than 8 times greater if invasive alien plants were to occupy the full extent of their potential range (Van Wilgen et al., 2008). These invasions come at a significant cost to the economy, estimated at about R6.5 billion per annum (about $0.3 \%$ of South Africa's GDP of around R2 000 billion), and with the potential to rise to $>5 \%$ of GDP if invasive plants were to be allowed to invade all of the suitable habitat (De Lange and Van Wilgen, 2010).

The importance of these impacts has long been recognised, and in 1995 led to the establishment of a national programme (Working for Water) to control invasive alien plants and reduce their negative impacts (Van Wilgen et al., 2011). The programme has an annual budget of R500 million and a number of criteria have been developed to prioritise and control operations to ensure that these funds are deployed to areas where they will be most cost-effective (see, for example, Roura-Pascual et al., 2009). Criteria include the magnitude of the impacts on water resources and rangeland condition, and the need to conserve biodiversity, reduce fire hazard and alleviate poverty. The impacts of invasive alien plants on surface water runoff and groundwater recharge are relatively well understood and can be used to set priorities. Although scientists recognise that invasive alien plants have negative impacts on water quality as well as quantity, a shortage of information regarding these impacts has prevented them from being considered in prioritisation exercises by institutions such as Working for Water.

This paper addresses that gap by reviewing the impacts of invasive alien plants on water quality. Our goal was to identify which impacts had been recognised and quantified, 
both internationally and in South Africa, as well as to identify important gaps in our knowledge.

\section{Methods}

We searched for published studies, as well as 'grey literature', which dealt with the impacts of invasive alien plants on water quality. We used keywords such as 'alien', 'invasive' and 'water quality' to compile a list of relevant papers and reports for both South African and international studies. We then consulted water quality specialists and experts in the field of invasive alien plant ecology to supplement the list where possible, especially with regard to studies relevant to South Africa. We divided the papers and reports into 4 categories, which we addressed separately. The choice of categories was guided by an assessment of the groups into which studies could be divided. The categories were:

- Implications of reductions in streamflow and groundwater storage. Reductions in stream flow and groundwater recharge rates are brought about by increases in evapotranspiration caused by invasive alien plants; this results in reduced dilution and greater concentrations of nutrients, pollutants and suspended solids in water.

- Plant biomass and nutrient cycling. Increased biomass and litter production associated with invasive alien plants could result in changes in litter chemistry, nitrogen fixation, and changes in soil chemistry in the natural biome which impact on water quality.

- Fire regimes, soil erosion and water quality. Invasive alien plants alter vegetation structure, increase fuel loads and change fire behaviour, which can lead to soil damage and erosion, thereby adversely affecting water quality.

- Aquatic alien plants and water quality. Alien plants that invade aquatic environments can directly affect water quality by their presence in or on water bodies.

\section{Results}

\section{Implications of reductions in streamflow and groundwater storage}

Many species of invasive alien plants, especially trees and shrubs, have higher evaporation rates than indigenous species do and, therefore, use more water than the vegetation they replace (Malan and Day, 2002). The increased evaporation results in reductions in river flows and reduced groundwater reserves (Malan and Day, 2002). The reduction in the amount of water in the river reduces its dilution capacity, resulting in increased concentrations of nutrients and pollutants, increased salinity and altered buffering capacity of the ecosystem (Malan et al., 2003; Enright, 2000; Nagler et al., 2008).

More studies have focused on the impacts of dilution capacity during flash floods and high runoff seasons than on the impacts of reduced water quantity (Table 1). Reduced dilution capacity, however, can also have severe impacts on water quality. Water with high salinity has an unpleasant taste, poses a human health risk (DWAF, 1996), reduces crop yields and causes corrosion of industrial pipes (DEAT, 2000). High concentrations of point-source pollutants such as heavy metals can be toxic to human health and tend to bioaccumulate in the riparian vegetation (Mishra and Tripathia, 2008; De Wet et al., 1990). Increased nutrient concentrations contribute to eutrophication processes, resulting in potentially toxic algal blooms (Malan and Day, 2002; Malan and Day, 2003a,2003b; Rossouw, 2004).

Only one study attributed these effects directly to invasive alien plants. Invasions of Tamarix chinensis were found to have almost quadrupled groundwater salinity (from $2250 \mathrm{mg} / \ell$ to 5 000 and $10000 \mathrm{mg} / \ell$ ) by increasing evapotranspiration in the Colorado River in the United States (Nagler et al., 2008).

Very few studies have quantified the impacts of invasive alien plants on stream flow, runoff or groundwater recharge. The initial studies in South Africa (Le Maitre et al., 1996; Le Maitre et al., 2000) used measured reductions in stream flow arising from forestry plantations (see Dye, 1996) to estimate the potential effects of invasion of pristine ecosystems by similar species. This approach is justifiable because invasions also develop into dense stands with similar structure and biomass, although plantations are managed to maintain high wood production and invasions are not. In addition, invasions often include the river floodplains and riparian zones, where trees have high transpiration rates (Scott 1999; Dye and Jarmain 2004). Dye and Poulter (1995), Prinsloo and Scott (1999), and Dye and Jarmain (2004) quantified the increases in surface runoff that follow the clearing of invasive trees and shrubs, which provides support for the assumptions made in earlier studies. The magnitude of reductions depends on the annual rainfall, and the invasive alien species concerned. Typical examples of results from plantations include: an $82 \%$ reduction in stream flow in the KwaZulu-Natal Drakensberg 20 years after planting grasslands with pines (Bosch 1979); a 55\% reduction in stream

Table 1

Studies that have quantified the effects of reduced water volumes on the quality of water, arising from the concentration of solids, nutrients or pollutants. Abbreviations are as follows: TDS (total dissolved solids); EC (electric conductivity); $\uparrow$ (increase); $\downarrow$ (decrease); $\mathrm{NO}_{3}^{-}$(nitrates); P (phosphate). Table adapted from Malan and Day (2002).

\begin{tabular}{|l|l|l|l|l|}
\hline Dilution change & TDS/EC/ salinity & Nutrients & Temperature/pH & Other \\
\hline Concentration & & & $\begin{array}{l}\mathrm{Na}^{+}, \mathrm{K}^{+}, \mathrm{Cl}^{-}, \mathrm{SO}_{4}^{-2}, \mathrm{Ca}^{+2} \uparrow \\
\text { low flow; } \\
\text { Rivper Hennops } \\
\text { (Toerien and Walmsley, } \\
\text { 1979) }\end{array}$ \\
\hline Dilution & $\begin{array}{l}\downarrow \text { TDS and } \\
\text { Conductivity; Ntuze } \\
\text { tributary, (South } \\
\text { Africa) (Kelbe and } \\
\text { Germishuyse, 1999); } \\
\downarrow \text { TDS; Modder River, } \\
\text { (South Africa) (Koning } \\
\text { et al., 2000) }\end{array}$ & $\begin{array}{l}\mathrm{NO}_{3}^{-} \downarrow \text { and } \mathrm{P} \uparrow \text { in winter storm, } \mathrm{NO}_{3}^{-} \\
\text {mountain stream (South Africa) } \\
\text { (Britton et al., 1993); } \mathrm{NO}_{3}^{-} \uparrow \text { and } \mathrm{P} \uparrow, \\
\text { Modder River, (South Africa) (Koning } \\
\text { et al., 2000); } \uparrow \text { Total N and Total P, } \\
\text { Senqu, Matsoku, Senqunyane Rivers, } \\
\text { (Lesotho) (Skoroszewski, 1999) }\end{array}$ & $\begin{array}{l}\mathrm{pH} \downarrow \text {; fynbos } \\
\text { mountain } \\
\text { stream (South } \\
\text { Africa) (Britton } \\
\text { et al., 1993) }\end{array}$ & $\begin{array}{l}\uparrow \text { Turbidity; Ntuze River, } \\
\text { Modder River, (South } \\
\text { Africa) (Kelbe and } \\
\text { Germishuyse, 1999); } \uparrow \\
\text { TDS and turbidity, Senqu, } \\
\text { Matsoku, Senqunyane } \\
\text { Rivers, (Lesotho) } \\
\text { (Skoroszewski, 1999) }\end{array}$ \\
\hline
\end{tabular}


flow in the Western Cape 23 years after planting pines in fynbos (Van Wyk, 1987); and the total drying up of streams 6 to 12 years after completely replacing grassland with pines and eucalypts in the Mpumalanga Province (Van Lill et al., 1980).

More recently, Cullis et al. (2007) calculated that the total loss of usable water due to the invasion of alien plants in catchments receiving more than $800 \mathrm{~mm}$ of rainfall per year is $695 \mathrm{Mm}^{3}, 75 \%$ of which is due to invasions of riparian areas by alien plants. Combined with non-riparian invasive alien plants, this accounts for $4 \%$ of the total registered water use in South Africa.

Our review revealed that few studies have quantified the effects of invasions on water quality resulting from increases in evapotranspiration and, thus, decreases in river flows and dilution capacity. Most impacts are inferred and are not supported by measured data. The influence of invasive alien plants on water quality is intimately linked to site-specific processes, making it difficult to isolate causal factors (Malan, 2011)

Evapotranspiration rates are also site- and season-specific, which makes it difficult to generalise findings.

\section{Plant biomass, eutrophication and nutrient cycling}

Alien invasive plants change the amount and structure of biomass, which changes carbon and nutrient dynamics (Table 2).
Invasive alien plants typically grow more rapidly, often increasing the proportion of biomass contributed by alien plants. This includes leaves, bark, seed, flowers and twigs that become 'terrestrial litter' after abscission (Aerts, 1997). Such litter enters and is retained in water bodies, where its rate of breakdown by invertebrate feeding as well as fungal and bacterial activity can differ from that of inputs from indigenous plants (Stewart and Davies, 1990). The often large differences in litter inputs from invasive alien plants relative to indigenous species can dramatically alter the nutrient cycle in ecosystems (Stock et al., 1995).

Increases in the biomass contributed by alien plants can increase the amount of metabolised nutrients, which escalates natural eutrophication processes (Kalff, 2002) as well as freefloating and rooted aquatic macrophytes invasions (Lee, 1973). Eutrophication leads to gradual changes in the plant and animal populations, the development of potentially toxic algal blooms and therefore a slow decline in water and habitat quality (Kalff, 2002).

The level of impact that litter from invasive alien plants has on nutrient cycles is determined by vegetative spread, plant structure, phenology, plant water and nutrient uptake efficiency, photosynthesis type, presence of symbionts and nitrogen fixation, phosphorus content and tissue chemistry (such as allelopathy) (Ehrenfeld, 2003).

\begin{tabular}{|c|c|c|c|c|}
\hline $\begin{array}{l}\text { Examples fron } \\
\text { on bic }\end{array}$ & $\begin{array}{l}\text { n local and internat } \\
\text { omass, litter produc }\end{array}$ & $\begin{array}{l}\text { onal literature of th } \\
\text { tion, and litter and }\end{array}$ & $\begin{array}{l}\text { Table } 2 \\
\text { effects of plants that are impo } \\
\text { oil chemistry. Arrows indicate } \mathrm{i}\end{array}$ & $\begin{array}{l}\text { tant invasive species in South Africa } \\
\text { ccreases }(\uparrow) \text { or decreases }(\downarrow) \text {. }\end{array}$ \\
\hline Species & Biomass & Terrestrial littering & Litter chemistry & Soil chemistry changes and increased $\mathbf{N}$ \\
\hline $\begin{array}{l}\text { Acacia } \\
\text { cyclops }\end{array}$ & $\begin{array}{l}\text { 个biomass (South } \\
\text { Africa, Western } \\
\text { Cape) }\end{array}$ & $\begin{array}{l}\text { Leaf and pod litter } \\
\text { build-up (Kenya; } \\
\text { South Africa) })^{\text {b,d,f,g }}\end{array}$ & $\begin{array}{l}\uparrow \text { Phosphates (South Africa) }{ }^{\mathrm{g}, \mathrm{f}} \\
3 \times \mathrm{N} \text { content (South Africa, } \\
\text { coastal Western Cape) }\end{array}$ & $\begin{array}{l}\uparrow \text { decomposition rate and rate of } \\
\text { nutrient cycling (South Africa) }{ }^{\mathrm{c}}, \uparrow \text { soil } \\
\text { organic C } \mathrm{g}, \mathrm{c} ; \uparrow \text { total P (South Africa, } \\
\text { Western Cape) }^{\mathrm{f}}\end{array}$ \\
\hline $\begin{array}{l}\text { Acacia } \\
\text { dealbata }\end{array}$ & & & & $\begin{array}{l}\text { High polyphenol content suggests a } \\
\text { slow release rate of } \mathrm{N} \text { (Kenya) }{ }^{\mathrm{b}}\end{array}$ \\
\hline $\begin{array}{l}\text { Acacia } \\
\text { longifolia }\end{array}$ & $\begin{array}{l}\uparrow \text { plant biomass } \\
\text { and rapid growth } \\
\text { (South Africa) }^{\mathrm{d}, \mathrm{g}}\end{array}$ & $\begin{array}{l}\uparrow \text { litter mass below } \\
\text { canopy (South } \\
\text { Africa, Western } \\
\text { Cape) }\end{array}$ & & \\
\hline $\begin{array}{l}\text { Acacia } \\
\text { mearnsii }\end{array}$ & $\begin{array}{l}\text { Dense growths. } \uparrow \\
\text { overall biomass up } \\
\text { to } 10 \text { fold (South } \\
\text { Africa) })^{\text {a,d }}\end{array}$ & $\begin{array}{l}\uparrow \text { litter mass below } \\
\text { canopy (South } \\
\text { Africa) }^{\mathrm{d}}\end{array}$ & & $\begin{array}{l}\text { The high polyphenol content suggests } \\
\text { a slow release rate of } \mathrm{N} \text { due to com- } \\
\text { plexation of } \mathrm{N} \text { with reactive polyphe- } \\
\text { nols (Kenya) }\end{array}$ \\
\hline $\begin{array}{l}\text { Acacia } \\
\text { melanoxylon }\end{array}$ & & $\begin{array}{l}\uparrow \text { litter mass below } \\
\text { canopy (South } \\
\text { Africa) }\end{array}$ & & \\
\hline $\begin{array}{l}\text { Acacia } \\
\text { saligna }\end{array}$ & $\uparrow$ plant biomass ${ }^{\mathrm{a}}$ & $\begin{array}{l}\text { Dense litter layers } \\
\text { (South Africa) })^{b, c, g}\end{array}$ & $3 \times$ higher $\mathrm{N}$ content $(\text { Kenya })^{\mathrm{g}, \mathrm{b}}$ & $\begin{array}{l}\uparrow \text { soil N; } \uparrow \mathrm{Na}, \mathrm{Ca}, \mathrm{Mg}, \mathrm{K}, \mathrm{Mn} \text { and B, } \\
\downarrow \text { Fe (South Africa Western Cape) } \text { (e,j; }^{\mathrm{e}} \text {; } \\
\uparrow \mathrm{N} \text { leached into groundwater (South } \\
\text { Africa, Western Cape) }\end{array}$ \\
\hline $\begin{array}{l}\text { Arundo } \\
\text { donax }\end{array}$ & $\begin{array}{l}\text { Form dense stands } \\
\text { on riverbanks, } \\
\text { (South Africa) }^{g, 1}\end{array}$ & & & \\
\hline $\begin{array}{l}\text { Chromolaena } \\
\text { odorata }\end{array}$ & $\begin{array}{l}\uparrow \text { plant biomass } \\
\text { (South Africa, }^{\mathrm{m}} \\
\text { KwaZulu-Natal) }^{\mathrm{m}}\end{array}$ & $\begin{array}{l}\uparrow \text { dry leaf litter } \\
\text { (Ghana) }^{\mathrm{n}}\end{array}$ & & $\begin{array}{l}\text { Nutrient demand has a marked effect } \\
\text { on nutrient cycling (India) }\end{array}$ \\
\hline $\begin{array}{l}\text { Eucalyptus } \\
\text { camaldulensis }\end{array}$ & & & $\begin{array}{l}\text { Leaf litter contains water } \\
\text { soluble phenols that may affect } \\
\text { acidity and nitrification pro- } \\
\text { cesses (Congo) }{ }^{q} \text {; leaves have } \\
\text { waxy cuticles and contain tan- } \\
\text { nins (Spain) }\end{array}$ & $\downarrow$ decomposition rate (Spain) ${ }^{\mathrm{p}}$ \\
\hline
\end{tabular}




\begin{tabular}{|c|c|c|c|c|c|c|}
\hline \multicolumn{7}{|c|}{$\begin{array}{l}\text { Table } 2 \text { (continued) } \\
\end{array}$} \\
\hline IAP & \multicolumn{2}{|l|}{ Biomass } & \multicolumn{2}{|c|}{ Terrestrial littering } & Litter chemistry & Soil chemistry changes and increased $\mathrm{N}$ \\
\hline $\begin{array}{l}\text { Eucalyptus } \\
\text { grandis }\end{array}$ & \multicolumn{2}{|c|}{$\uparrow$ Plant biomass $^{g}$} & & & & \\
\hline $\begin{array}{l}\text { Hakea drupacea } \\
\text { and gibbosa }\end{array}$ & \multicolumn{2}{|c|}{ Form dense thickets } & & & & \\
\hline Hakea sericea & \multicolumn{2}{|c|}{$\begin{array}{l}\text { Form dense thickets, } \\
\uparrow \text { plant biomass (50 - } \\
60 \%) \text {, (South Africa, } \\
\text { Western Cape) })^{\mathrm{a}, \mathrm{r}}\end{array}$} & & & & \\
\hline Lantana camara & & & \multicolumn{2}{|c|}{$\begin{array}{l}\text { Nutrient return through } \\
\text { litterfall }(\mathrm{kg} / \text { ha per } \\
\text { year) N: } 94 \text { P:5 (India) }\end{array}$} & & $\begin{array}{l}\uparrow \text { Nutrient content in soil }(\mathrm{kg} / \mathrm{ha}) \mathrm{N}: \\
2932 \mathrm{P}: 111 \text { (India) }{ }^{\mathrm{s}} ; \uparrow \text { decomposition } \\
\text { rates in soil (India) })^{\mathrm{g}, \mathrm{s}} ; \uparrow \text { soil biomass, } \\
\text { (India) }^{\mathrm{g}, \mathrm{s}}\end{array}$ \\
\hline Pinus patula & \multicolumn{2}{|c|}{$\begin{array}{l}\uparrow \text { Plant biomass Australia, } \\
\text { South Africa) })^{\mathrm{i}, \mathrm{a}}\end{array}$} & \multicolumn{2}{|l|}{$\begin{array}{l}\uparrow \text { Litter mass } \\
\text { (Australia) }^{i}\end{array}$} & & $\begin{array}{l}\downarrow \mathrm{P}, \mathrm{K}, \mathrm{Ca}, \mathrm{Mg}, \text { (South Africa) }^{\mathrm{d}, \mathrm{g}} \text {; } \\
\text { slow decomposition (South Africa) }^{\mathrm{d}}\end{array}$ \\
\hline Pinus pinaster & & & \multicolumn{2}{|c|}{$\begin{array}{l}\text { Higher rate of self } \\
\text { pruning compared to } \\
\text { other Pinus (South } \\
\text { Africa) }\end{array}$} & & $\underset{\mathrm{d}, \mathrm{g}, \mathrm{c}}{\downarrow \text { decomposition rates (South Africa) }}$ \\
\hline Pinus radiata & \multicolumn{2}{|c|}{$\begin{array}{l}\uparrow \text { Plant biomass } \\
\text { (Australia; South } \\
\text { Africa) }{ }^{\mathrm{a}, \mathrm{i}} \text {. }\end{array}$} & & & $\begin{array}{l}\text { Rapid nutrient } \\
\text { cycling, fast decom- } \\
\text { position rates }{ }^{\mathrm{w}}\end{array}$ & $\begin{array}{l}\uparrow \text { soil biomass and increased leach- } \\
\text { ing (Australia) } \text { g,u }^{\mathrm{u}} \text {; increased total } \mathrm{P} \text {, } \\
\mathrm{K}, \mathrm{Ca},(\text { Australia) } \\
\mathrm{g}, \mathrm{u}\end{array}$ \\
\hline $\begin{array}{l}\text { Prosopis } \\
\text { glandulosa }\end{array}$ & & & \multicolumn{2}{|c|}{$\begin{array}{l}\text { Annual shedding of } \\
\text { leaves (USA) }\end{array}$} & $\begin{array}{l}\text { Allellopathic } \\
\text { N-fixing }(\mathrm{USA})^{\mathrm{v}} \\
\text { L-tryptophan }^{\mathrm{w}} \\
\end{array}$ & $\begin{array}{l}\mathrm{N} \text { increment } 26-175 \mathrm{~kg} \mathrm{~N} / \text { ha per } \\
\text { year under canopy }(\mathrm{USA})^{\mathrm{v}}\end{array}$ \\
\hline Quercus spp. & & & \multicolumn{2}{|c|}{$\begin{array}{l}\text { Litterfall in winter, } \\
\text { atypical compared to } \\
\text { indigenous spp. (South } \\
\text { Africa, Western Cape) } \\
\text { x }\end{array}$} & & \\
\hline $\begin{array}{l}\text { Tamarix } \\
\text { chinensis }\end{array}$ & & & & & & $\begin{array}{l}\uparrow \text { surface soil salinity, }(U S A)^{\mathrm{y}} ; \\
\text { temporal patterns of minerals and } \\
\text { nutrients different }(U S A)^{\mathrm{g}, \mathrm{z}}\end{array}$ \\
\hline \multicolumn{2}{|c|}{$\begin{array}{l}\text { a Van Wilgen and Richardson, } 1985 \\
\text { b Palm et al.,2001 } \\
\text { c Witkowski, } 1991 \\
\text { d Versfeld and Van Wilgen, } 1986 \\
\text { e Musil, } 1993 \\
\text { f Witkowski and Mitchell, } 1987 \\
\text { g Ehrenfeld, } 2003\end{array}$} & \multicolumn{2}{|c|}{$\begin{array}{l}\text { h Stock et al., } 1995 \\
\text { i Virtue and Melland, } 2003 \\
\text { j Musil and Midgely, } 1990 \\
\text { k Jovanovic et al., } 2009 \\
\text { l Milton, } 2004 \\
\text { m MacDonald, } 1983 \\
\text { n Braimah and Timbilla, } 1991\end{array}$} & \multicolumn{2}{|c|}{$\begin{array}{l}\text { o Ramakrishnan, } 1992 \\
\text { p Pozo et al., } 1998 \\
q \text { Chapuis-Lardy, } 2002 \\
\text { r Awad, } 2002 \\
\text { s Bharat et al., } 1994 \\
\text { t Moran et al., } 1999 \\
\text { u Feller, } 1982\end{array}$} & $\begin{array}{l}\text { urkart, } 1976 \\
\text { Versfeld and Donald, } 1991 \\
\text { tewart and Davies, } 1990 \text { y } \\
\text { gler et al., } 2008 \\
\text { tromberg, } 1998\end{array}$ \\
\hline
\end{tabular}

*Reported increases and decreases in this table are in relation to indigenous species.

Nitrogen fixation, for example, is a natural process by which nitrogen gas $\left(\mathrm{N}_{2}\right)$ is converted to biologically-useful ammonia $\left(\mathrm{NH}_{3}\right)(\mathrm{McNeill}$ and Unkovich, 2007). In a symbiotic relationship with bacteria, legumes form nodules on the roots to fix nitrogen gas which can then be used by either plants or animals (Lindemann and Glover, 2003). Nitrogen fixation by legumes can be in the range of 2.5-7.4 kg of nitrogen per 1000 $\mathrm{m}^{2}$ per year in natural ecosystems, and several hundred kilograms in a cropping system (Lindemann and Glover, 2003).

The majority of nitrogen-fixing plants are in the flowering legume family Fabaceae, of which the genus Acacia is the second largest, with over 900 species. Australian acacias are important invaders of South African fynbos areas in the Western Cape (Yelenik et al., 2004; Jovanovic et al., 2009). Fynbos areas are generally nutrient-poor and the invasion by nitrogen-fixing acacias increases nitrogen input and soil fertility, thus allowing for Acacia species to propagate and outcompete indigenous species (Stock et al., 1995). N-fixation has been reported for Acacia cyclops (Stock et al., 1995; Virtue and Melland, 2003), A. dealbata (Musil, 1993), A. mearnsii (Musil,
1993) and A. saligna (Stock et al., 1995).

A study of $A$. saligna in the Western Cape showed that groundwater in invaded and recently cleared plots had elevated $\mathrm{NO}_{3}{ }^{-}$and $\mathrm{NO}_{2}{ }^{-}$concentrations (up to $12 \mathrm{mg} / \ell$ ) compared to groundwater in natural fynbos plots (up to $3.3 \mathrm{mg} / \ell$ ) (Stock et al., 1995; Jovanovic et al., 2009). The presence of A. saligna, as well as the nutrient leaching that occurred after its removal, resulted in seasonal nitrogen concentrations that were higher than the water quality targets for domestic use $\left(\mathrm{NO}_{\mathrm{x}}<6 \mathrm{mg} / \ell\right)$ (Jovanovic et al., 2009; DWAF, 1993). Clearing of $A$. saligna resulted in an initial flushing of nitrogen out of the soil, but nitrogen concentrations normalised after that. The results suggest that removal of the alien plants would be beneficial from both a water quantity as well as water quality perspective (Jovanovic et al., 2009).

Allelopathy is the process through which invasive plants such as eucalyptus (Al-Naib and Al-Mousawi, 1976), pines (Durvey et al., 1999), Chromolaena and Lantana (Sheeja, 1993) produce biochemicals that influence the growth, survival and reproduction of indigenous species. These biochemicals can act 
as antibiotics in certain soils, possibly impacting on nitrogen cycles (Couto and Betters, 1995). Phenolics and volatile compounds can be released from eucalyptus foliage (Al-Naib and Al-Mousawi, 1976). These may subsequently impact on water quality through soil erosion or surface runoff processes. These possible impacts of allelochemicals on water quality have, however, not yet been evaluated.

Many South African alien invaders, for example trees in the genera Acacia and Pinus, increased the biomass of an invaded area, by either dense overgrowth or excessive terrestial littering, and therefore add additional nutrients to the system (Van Wilgen and Richardson, 1985; Versfeld and Van Wilgen, 1986; Ehrenfeld, 2003; Virtue and Melland, 2003). Alien invasive plants are capable of changing the soil chemistry by either slow decomposition processes or nitrogen-fixing which, in turn, is assumed to impact on the water quality (Jovanovic et al., 2009; Ehrenfeld, 2003), although there is very little supporting evidence of this. There is a significant gap in our understanding of the changes in soil chemistry, and the resulting changes in soil and groundwater chemistry and overall water quality. The impacts of alien invasive biomass on eutrophication processes are therefore a complex matter, in need of quantified data and extended research. As the primary nutrient responsible for eutrophication is phosphorus (Lee, 1973), the nitrogen-fixing and cycling abilities of the alien invaders alone will not account for their contribution to these processes. Fynbos produces large amounts of secondary plant compounds, known as polyphenolics, which decompose to form humic and other weak organic acids (Dallas and Day, 2004). These leaching humic acids are known to darken the water, decrease the $\mathrm{pH}$ and reduce the amount of phosphorus in water. Berzelia lanuginosa (Bruniaceae) and Elegia thyrsifera (Restionaceae), a fynbos shrub and reed, respectively, were studied for their decomposing impacts on soluble reactive phosphorus (SRP), ammonium and polyphenol concentrations in water (Raubenheimer and Day, 1991). The studied fynbos showed a linear leached polyphenol concentration in water over time which later complexed with SRP, reducing the leached amount of biochemicallyavailable phosphate. For fertiliser applications, humic acid containing manures are frequently added to soils to increase the biochemically-available amount of phosphorus (Winarso et al., 2011). The presence of dissolved humic compounds can therefore either reduce the amount of phosphate or increase the biochemically-available phosphorus in a given ecosystem (DWAF, 1996b), depending on the $\mathrm{pH}$ and available bacteria (Winarso et al., 2011). Although phosphorus is seldom found in quantity in unpolluted water (Dallas and Day, 2004), the impact alien invasive plants have on phosphorus cycling mechanisms and processes will also have to be investigated more closely to determine their holistic impact on eutrophication processes.

\section{Fire regimes, soil erosion and water quality}

Plant invasions can change the structure, biomass (Van Wilgen and Richardson, 1985; Jayiya et al., 2004) and spatial distribution of plant parts in invaded vegetation (Brooks et al., 2004), leading to increases in fire intensity (Versfeld and Van Wilgen, 1986; Scott and Van Wyk, 1990). More intense fires generate water-repellent layers in the soil, leading to increased soil erosion after rains (Smith et al., 2011). Erosion increases sediment loads in water, affecting its quality.

Alien plant invasions influence the fire regime of an invaded area in the following ways (Brooks et al., 2004; Keeley, 2009):
- Fuel loads. Invasion of mountain fynbos by pines can increase biomass in fynbos and grasslands by up to $300 \%$ (Versfeld and Van Wilgen, 1986). Studies in South Africa have assessed a number of alien invasive species in terms of biomass and fire intensity (Van Wilgen and Richardson, 1985; Jayiya et al., 2004). Invaded areas typically have greater fuel loads than indigenous vegetation: for example A. cyclops ( $317 \%$ increase), A. saligna (50\% increase), $H$. sericea (60\% increase) and $P$. pinaster ( $743 \%$ increase). Increased fuel loads have also been observed due to the accumulation of slowly decomposing litter from $P$. pinaster and P. patula (De Ronde, 1984; Morris, 1995).

\section{- Plant tissue chemistry (flammability and moisture}

content). Chromolaena odorata leaves contain essential oils, resulting in flammable foliage leading to fires that burn with higher intensity compared to indigenous plants (Pammenter et al., 1985). The moisture content (as percentage of oven-dry weight) of live foliage differed among invasive alien plants: A. cyclops $120-140 \%$, A. saligna $270 \%$, H. sericea $110 \%$, P. pinaster $118-175 \%$; this affects fire risk (Van Wilgen and Richardson, 1985; Jayiya et al., 2004).

- Horizontal and vertical continuity. Acacia cyclops and Pinus pinaster increased the vertical and horizontal continuity of fuels, facilitating fire spread (Jayiya et al., 2004). Arundo donax, a reed species that invades drainage lines, can increase the amount and especially the vertical continuity of fuel, causing more intense fires and carrying fires into the crowns of trees (Brooks et al., 2004). Chromolaena carries fires into the canopies of areas that generally don't burn with very high intensity (Zachariades and Goodall, 2000).

High intensity fires can lead to the development of water repellency, or 'hydrophobicity' in soil (Adams et al., 1970; DeBano and Conrad, 1976; DeBano, 1981; Keeley, 2009). The waterrepellent layer is formed as hydrophobic materials (such as resins) are volatized during fire near the soil surface and then distil downward according to the temperature gradient within the soil profile. Some $50-95 \%$ of the substances moving from burning litter into sand were recorded as being capable of causing water repellency (Savage, 1974). Hydrophobicity inhibits water infiltration and/or percolation and thus increases the proportion of overland flow, accelerating soil erosion (Scott and Van Wyk, 1992).

Soil erosion, caused by water repellency, increases the sediment load in a water resource. Sediment transport has been reported to increase up to 1459 times after fires (Smith et al., 2011). The sediment loads after fires are also determined by the slope $\left(9.9 \mathrm{t} / \mathrm{ha}\right.$ per year on $15^{\circ}$ slope versus $25.9 \mathrm{t} /$ ha per year on $32^{\circ}$ slope, (Scott, 1993)), fuel load, the soil geomorphology and the fire location relative to the riparian zone and the main channel flow (D.C. Le Maitre, personal observation). In addition, alien invasive plants typically suppress ground-cover and understorey vegetation and the absence of these shallow root systems increases the likelihood of soil loss after a fire (Scott et al., 1998).

The increased rate of sediment runoff on post-fire ground surfaces impacts on water quality and is region specific. The sediment runoff increases the turbidity and salinity, decreases pH (Bayley and Schindler, 1991), elevates water temperature, and increases nutrient loads (Smith et al., 2011), thereby accelerating eutrophication processes and temporarily increasing the concentrations of pollutants such as toxic heavy metals (Gallaher et al., 2002; Crouch et al., 2006; White et al., 2006; Smith et al., 2011) and the numbers of disease-carrying 


\begin{tabular}{|c|c|c|c|}
\hline \multicolumn{4}{|c|}{$\begin{array}{c}\text { Table } 3 \\
\text { Examples of studies that have quantified the combined effects of fire and alien plant invasions in South Africa }\end{array}$} \\
\hline Location & $\begin{array}{l}\text { Invasive alien plant } \\
\text { species }\end{array}$ & Impact & Sources \\
\hline $\begin{array}{l}\text { Jonkershoek, } \\
\text { Western Cape }\end{array}$ & Pinus radiata & $\begin{array}{l}6 \mathrm{t} / \mathrm{ha} \text { of soil was lost following fires in pine stands in a } \\
\text { commercial plantation compared to } 0.1 \mathrm{t} / \mathrm{ha} \text { following fire } \\
\text { in adjacent fynbos. }\end{array}$ & $\begin{array}{l}\text { Scott, Versfeld and } \\
\text { Lesch, } 1998\end{array}$ \\
\hline $\begin{array}{l}\text { Drakensberg, } \\
\text { KwaZulu-Natal }\end{array}$ & Pinus patula & $\begin{array}{l}37 \mathrm{t} / \mathrm{ha} \text { of soil was lost following fires in pine stands com- } \\
\text { pared to } 1.8 \mathrm{t} / \mathrm{ha} \text { in adjacent grassland. }\end{array}$ & $\begin{array}{l}\text { Van Wyk, 1985; Scott } \\
\text { and Van Wyk, } 1990\end{array}$ \\
\hline $\begin{array}{l}\text { Cape Peninsula, } \\
\text { Western Cape }\end{array}$ & $\begin{array}{l}\text { Acacia } \\
\text { cyclops and Hakea } \\
\text { suaveolens }\end{array}$ & $\begin{array}{l}\text { Fires in alien infested areas are, on average, about } 65 \% \\
\text { more severe (more damage) than fynbos fires. The change } \\
\text { in soil surface level was equivalent to } 113 \mathrm{~m}^{3} / \mathrm{ha} \text { or } 147 \\
\mathrm{t} / \mathrm{ha} \text { in infested areas. }\end{array}$ & Euston-Brown, 2000 \\
\hline $\begin{array}{l}\text { Cape Peninsula, } \\
\text { Western Cape }\end{array}$ & $\begin{array}{l}\text { Mixed stands of alien } \\
\text { Australian Acacia } \\
\text { species, Pinus pinaster } \\
\text { and Hakea sericea }\end{array}$ & $\begin{array}{l}\text { The degree of damage to the soil following fires was in } \\
\text { proportion to the degree of invasion, with heavily-invaded } \\
\text { sites being the worst affected. }\end{array}$ & $\begin{array}{l}\text { Van Wilgen and Scott, } \\
2001\end{array}$ \\
\hline $\begin{array}{l}\text { Wemmershoek, } \\
\text { Western Cape }\end{array}$ & Hakea sericea & $\begin{array}{l}\text { A wildfire in dense, felled stands of Hakea led to high fire } \\
\text { intensities and severe erosion following fires. }\end{array}$ & $\begin{array}{l}\text { Richardson and Van } \\
\text { Wilgen, 1986; Holmes } \\
\text { et al., } 2000\end{array}$ \\
\hline $\begin{array}{l}\text { Drakensberg, } \\
\text { KwaZulu-Natal } \\
\end{array}$ & Eucalyptus fastigata & $\begin{array}{l}\text { Measured soil losses on afforested slopes of } 55 \mathrm{t} / \mathrm{ha} \text { were } \\
\text { recorded with } 10 \mathrm{t} / \mathrm{ha} \text { sediment in stream. }\end{array}$ & $\begin{array}{l}\text { Scott and Schulze, } \\
1992\end{array}$ \\
\hline $\begin{array}{l}\text { Kouga Mountains, } \\
\text { Eastern Cape }\end{array}$ & Acacia mearnsii & $\begin{array}{l}\text { Soil movement increased on slopes which are invaded and } \\
\text { then cleared of Acacia mearnsii, with erosion rates dou- } \\
\text { bling on invaded slopes. }\end{array}$ & Van der Waal, 2009 \\
\hline
\end{tabular}

micro-organisms (Crouch et al., 2006; Smith et al., 2011; Doerr et al., 2011; Smith et al., 2011).

There are several South African studies that document increased erosion rates after fire events (Table 3), confirming international experience that has also documented negative effects of fire on water quality (in Australia by Lane et al. (2006), Wilkinson et al. (2009) and Sheridan et al. (2007); in Canada by Petticrew et al. (2006); in the United States by Reneau et al. (2007) and Moody and Martin (2009)).

\section{Aquatic alien plants and water quality}

Several alien aquatic plant species are important invaders of rivers and water bodies in South Africa. These plants, including Eichhornia crassipes (water hyacinth), Pistia stratiotes (water lettuce), Salvinia molesta (kariba weed), Myriophyllum aquaticum (parrot's feather) and Azolla filiculoides (red water fern) have become relatively widespread, forming dense mats in nutrient-rich aquatic ecosystems, either as floating weeds or rooted to shallow sediments or river banks (e.g., parrots feather).

Invasions of aquatic weeds are associated with a range of impacts on water quality (Table 4). Dense mats of these weeds can impede water flow, which increases the rate of siltation in water bodies, and inhibit the diffusion of air into water, resulting in lower concentrations of dissolved oxygen (Raid and Munshi, 1979; Téllez et al., 2008). Lower oxygen concentrations, combined with the increased amounts of organic detritus that collect beneath these floating mats, can increase sediment accumulation rates and accelerate eutrophication processes. Increased eutrophication can be lethal to fish, cause algal blooms and render the water toxic and uninhabitable for native animal and plant species (Pieterse, 1989). Dense mats of floating plants limit light penetration and thereby prevent the development of planktonic algal blooms, a typical result of eutrophication. Typical examples were seen with infestations of E. crassipes in Lake Victoria (Mailu, 2001) and S. molesta in Lake Kariba on the Zambezi River (Williams and Hecky, 2005). Although the eutrophication of these water bodies is primarily due to anthropogenic inputs (Mailu, 2001; Williams and Hecky, 2005), the invasion and rapid spread of aquatic weeds are indicators of declining water quality through eutrophication (Hill and Olckers, 2001).

Invasions by aquatic weeds have been linked to increases in water-borne, water-based and water-related diseases. Eichhornia crassipes infestations have been linked to increases in the gastropod vectors (Biomphalaria and Bulinus) that act as an intermediate host for schistosomiasis (bilharzia) in Lake Victoria (Okedi, 1990; Masifwa et al., 2001). Eichhornia crassipes has also been shown to adsorb Vibrio cholerae from contaminated water in Bangledesh (Spira et al., 1981). Salvinia molesta provides habitat for mosquitoes, which are vectors for diseases such as dengue fever, elephantiasis, encephalitis and malaria (Oliver, 1993) and S. molesta infestations have assisted in the spread of these diseases in Sri Lanka. The proliferation of $P$. stratioides on Lake Guiers in the River Senegal has accelerated the rapid spread of schistosomiasis, which affected up to $80 \%$ of the population of some lakeside villages (Cogels et al., 1997). Azolla filiculoides, which is known to be nitrogenfixing, has a symbiotic relationship with cyanobacteria, which produce the neurotoxic non-protein amino acid $\beta$-methylaminoL-alanine (BMAA). Consumption of BMAA causes serious neurodegenerative disease such as amyotrophic lateral sclerosis/parkinsonism-dementia complex (AL-SPDC) (Cox et al., 2003). Biomagnification of BMAA tin the Guam ecosystem, has increased the incidence of amyotrophic lateral sclerosis in humans 50- to 100-fold (Cox et al., 2003). Production of known neurotoxins has also been considered phylogenetically unpredictable. A single neurotoxin, $\beta-N$-methylamino-L-alanine, may be produced by all known groups of cyanobacteria, including cyanobacterial symbionts and free-living cyanobacteria. The ubiquity of cyanobacteria in terrestrial, as well as freshwater, brackish, and marine environments, suggests a potential for 
widespread human exposure (Cox et al., 2005).

Of the aquatic weeds reported on here, only A. filiculoides has been reported to exhibit nitrogen-fixing abilities due to its symbiotic association with cyanobacteria (Hussner, 2010). Symbiotic relationships between cyanobacteria and $S$. molesta and $E$. crassipes were also observed, but nitrogen-fixation occurred on a much smaller scale compared to Azolla spp. (Barik et al., 2000). Increases in cyanobacteria numbers caused by their symbiotic relationship with aquatic weeds, add to the eutrophication processes in the water resource.

Control operations aimed at reducing the extent of invasive aquatic weed mats can also have an impact on water quality. Submerged, emergent and floating water plants are often controlled using a variety of herbicides such as diquat, glyphosate, amitrole and the amine and acid formulations of 2,4-D (Williams and Hecky, 2005). This exposes humans, fish and livestock to potentially toxic chemicals in their drinking water (Williams and Hecky, 2005). Uncleared, dead or decaying weed soon turns into rotting biomass that can lead to localised de-oxygenation, contributing to eutrophication and other detrimental impacts upon the water body (Mallya, 1999). Decaying biomass may also result in the water having an unpleasant taste and odour (Jones, 2001).

In general, a dramatic reduction in the concentration of dissolved oxygen is observed and slightly more acidic conditions are expected for all of the aquatic invasions reviewed (see Table 4). The 5 invasive aquatic plant species investigated in this study extract phosphate, nitrogen and various heavy metals from water, to various degrees. It is due to this uptake capability of aquatic weeds that many reports and evaluations suggest their possible use in the removal of toxic heavy metals from mining wastewater (Mishra and Tripathia, 2008). The benefits of heavy metal extraction by the weeds have, however, not yet been exploited to balance their negative impact on water quality.

The available literature suggests that $E$. crassipes has the greatest impact on water quality, of the 5 species. It has

\begin{tabular}{|c|c|c|c|c|c|c|}
\hline \multicolumn{7}{|c|}{$\begin{array}{l}\text { Table } 4 \\
\text { The specific and non-specific impacts that aquatic weeds have on pH and the concentrations of heavy metals, dissolved } \\
\text { oxygen, nitrogen and phosphate in water resources. Arrows indicate increases }(\uparrow) \text { or decreases }(\downarrow) \text {. }\end{array}$} \\
\hline $\begin{array}{l}\text { Aquatic } \\
\text { weed }\end{array}$ & \begin{tabular}{|l|} 
Non-specific impacts \\
\end{tabular} & $\begin{array}{l}\text { Heavy metal } \\
\text { uptake }\end{array}$ & $\begin{array}{l}\text { Dissolved } \mathrm{O}_{2} \text { and } \\
\mathrm{pH}\end{array}$ & $\begin{array}{l}\text { Nitrogen and } \\
\text { phosphate } \\
\text { uptake }\end{array}$ & Comments & Example \\
\hline $\begin{array}{l}\text { Water } \\
\text { hyacinth } \\
\text { (floating) }\end{array}$ & $\begin{array}{l}\text { Bad odour, turbidity and loss } \\
\text { of light }^{\text {a }} \text {; reduced water move- } \\
\text { ment }^{\text {a }} \text {; increase in waterborne } \\
\text { diseases; impacts on agri- } \\
\text { culture, hydroelectric power } \\
\text { generation, fisheries, lake trans- } \\
\text { port, recreation and water sup- } \\
\text { ply (South Africa, Zimbabwe, } \\
\text { Zambia, Lake Victoria) })^{\text {b,c }} \\
\end{array}$ & $\begin{array}{l}\text { Absorption of }(\mathrm{Fe}, \\
\mathrm{Zn}, \mathrm{Cu}, \mathrm{Cr} \text { and } \\
\mathrm{Cd})(\text { India) }\end{array}$ & $\begin{array}{l}\downarrow \mathrm{O}_{2}{ }^{\mathrm{e}}(4.1 \mathrm{mg} / \ell-0.8 \\
\mathrm{mg} / \ell) \text { (Bhathwa } \\
\text { Pokhar, India); }{ }^{\mathrm{f}}, \downarrow \\
\mathrm{pH}(8.6 \text { to } 8.35) \\
\text { (Bhathwa Pokhar, }^{\text {India) }}{ }^{\mathrm{f}}\end{array}$ & $\begin{array}{l}\uparrow \mathrm{N} \text { and } \uparrow \mathrm{P} \\
\left.\text { (USA and }^{\text {Undia) }}\right)^{g, h}\end{array}$ & $\begin{array}{l}\text { Transpires } 3 \text { times } \\
\text { more water than native } \\
\text { plants (South Africa) } \\
\text { k; can survive in more } \\
\text { saline environments } \\
\text { than other aquatic } \\
\text { weeds }\end{array}$ & $\begin{array}{l}\text { Lake } \\
\text { Victoriab; }^{\text {bicto }} \\
\text { Lake Chivero, } \\
\text { Zimbabwe }^{1}\end{array}$ \\
\hline $\begin{array}{l}\text { Red water } \\
\text { fern } \\
\text { (floating) }\end{array}$ & $\begin{array}{l}\text { Bad odour, turbidity and } \\
\text { reduced light }{ }^{\mathrm{m}} \text {, reduced water } \\
\text { movement (Oba Lake, Nigeria) } \\
\mathrm{m} \text {; increase in waterborne dis- } \\
\text { eases; constrains agricultural, } \\
\text { recreational and conservation } \\
{\text { activities }(Z i m b a b w e)^{\mathrm{n}}}\end{array}$ & $\begin{array}{l}\text { Absorption of } \\
\mathrm{Fe}, \mathrm{Cu}, \mathrm{Ni}, \mathrm{Pb}, \\
\mathrm{Zn}, \mathrm{Mn} \text { and } \mathrm{Cr} \text {, } \\
\text { (Blesbok Spruit, }^{\text {South Africa) }}{ }^{\circ}\end{array}$ & $\begin{array}{l}\mathrm{O}_{2} \downarrow\left(12.6 \mathrm{~g} / \mathrm{m}^{3}\right. \\
\left.\text { to } 5.9 \mathrm{~g} / \mathrm{m}^{3}\right) ; \mathrm{pH} \\
\downarrow(8.93 \text { to } 7.81) \\
\text { (Guadiana River, } \\
\text { Spain) }\end{array}$ & $\begin{array}{l}\uparrow \mathrm{P} \\
\text { (Philippines) }^{\mathrm{q}}\end{array}$ & $\begin{array}{l}\text { Grows in water that } \\
\text { is low in nitrogen; } \\
\text { regarded as being } \\
\text { the most problematic } \\
\text { aquatic weed in Africa }\end{array}$ & $\begin{array}{l}\text { Poland, } \\
\text { Lower } \\
\text { Silesias; } \\
\text { Colesburg, } \\
\text { Eastern Cape }^{\mathrm{t}}\end{array}$ \\
\hline $\begin{array}{l}\text { Water } \\
\text { lettuce } \\
\text { (floating) }\end{array}$ & $\begin{array}{l}\text { Bad odour, increased turbid- } \\
\text { ity and loss of light (Oba Lake } \\
\text { Nigeria) }{ }^{\mathrm{m}} \text {; reduced water move- } \\
\text { ment }^{\mathrm{m}} \text {; increase in waterborne } \\
\text { diseases; constrains agricul- } \\
\text { tural, recreational and conser- } \\
\text { vation activities }\end{array}$ & $\begin{array}{l}\text { Absorption of } \mathrm{Fe} \text {, } \\
\mathrm{Zn}, \mathrm{Cu}, \mathrm{Cr} \text { and } \mathrm{Cd} \\
\text { (India) }^{\mathrm{d}}\end{array}$ & $\begin{array}{l}\mathrm{O}_{2} \downarrow\left(4.6 \mathrm{~g} / \mathrm{m}^{3} \text { to }\right. \\
2.6) \text { and } \mathrm{pH} \downarrow(\mathrm{Oba} \\
\text { Lake Nigeria })^{\mathrm{m}, \mathrm{w}}\end{array}$ & $\begin{array}{l}\uparrow \mathrm{N} \text { and } \uparrow \mathrm{P} \\
\text { (USA and } \\
\text { India) }{ }^{g, h}\end{array}$ & $\begin{array}{l}\text { Sensitive to salin- } \\
\text { ity (Silchar, India) } \\
\text { x; is being replaced } \\
\text { by more aggressive } \\
\text { hyacinth or water fern } \\
\text { (South Africa) }^{\mathrm{y}}\end{array}$ & $\begin{array}{l}\text { Pangani River } \\
\text { in Tanzaniaz; } \\
\text { Zimbabwe, } \\
\text { Manyame } \\
\text { Riveraa }^{\text {aa }}\end{array}$ \\
\hline $\begin{array}{l}\text { Parrots } \\
\text { feather } \\
\text { (sub- } \\
\text { merged) }\end{array}$ & $\begin{array}{l}\text { Blocking of pumps and interfer- } \\
\text { ence with recreational activities } \\
\text { (Manyame River, Zimbabwe) }^{\text {bb }}\end{array}$ & $\begin{array}{l}\mathrm{Cd}, \mathrm{Cu}, \mathrm{Pb}, \mathrm{Zn} \\
\text { accumulation } \\
\text { (Queensland, }^{\text {Q }} \\
\text { Australia) }\end{array}$ & $\begin{array}{l}\mathrm{O}_{2} \downarrow \text { and } \mathrm{pH} \downarrow \\
\text { (Portugal) }^{\mathrm{dd}}\end{array}$ & $\begin{array}{l}\uparrow \mathrm{N} \text { lower than } \\
\text { hyacinth and } \\
\text { water lettuce, } \\
\text { but similar } \uparrow \\
\mathrm{P} \text { (USA and } \\
\text { India) }{ }^{\mathrm{g}, \mathrm{h}}\end{array}$ & $\begin{array}{l}\text { Accumulation of per- } \\
\text { chlorate contaminants } \\
\text { (Georgia, USA) }^{\text {ee. }} \\
\text { can absorb pesticides } \\
\text { (Turkey) }^{\text {ff }}\end{array}$ & $\begin{array}{l}\text { Tagus River, } \\
\text { Portugal'sg; } \\
\text { Mokolo River, } \\
\text { Vaalwater } \\
\text { District }^{\text {th }}\end{array}$ \\
\hline $\begin{array}{l}\text { Kariba } \\
\text { weed } \\
\text { (floating) }\end{array}$ & 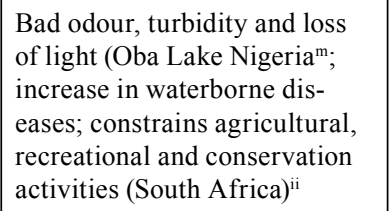 & $\begin{array}{l}\text { Absorption of } \\
\mathrm{Ni}, \mathrm{Cr} \text { and } \mathrm{Cd} \\
(\text { Nairobi, Kenya) }\end{array}$ & $\begin{array}{l}\mathrm{O}_{2} \downarrow(\text { Lake } \\
\text { Kariba) })^{\mathrm{jj}}\end{array}$ & $\begin{array}{l}\uparrow \mathrm{N} \text { and } \uparrow \mathrm{P} \\
(\mathrm{Queensland}, \\
\text { Australia) } \\
\text { (India) }^{\mathrm{h}}\end{array}$ & $\begin{array}{l}\text { Sensitive to salinity } \\
\text { (Silchar, India) }^{\mathrm{f}}\end{array}$ & $\begin{array}{l}\text { Lake Kariba, } \\
\text { Zimbabwe }^{\text {ll, }} \\
\text { Sepik River, } \\
\text { Papua New } \\
\text { Guinea }^{\mathrm{mm}}\end{array}$ \\
\hline
\end{tabular}

a) Ashton and Mitchell, 1989; b) Hill, 1999b; c) Bright, 1998; d) Mishra and Tripathia, 2008; e) Khedr, 1997; f) Raid and Munshi, 1979; g) Polomski et al., 2009; h) Tripathi et al., 1991; i) Jadhav et al,. 2008; k) De Groot, 1993; l) Brendock et al., 2003; m) Sridhar and Sharma, 1985; n) Gratwicke and Marshall, 2001; o) De Wet et al., 1990; p) Téllez et al., 2008; q) Rains and Talley, 1979; r) Ashton, 1992; s) Szcześniak et al., 2009; t) Oosthuizen and Walters, 1961; w) Sridhar and Sharma, 1980; x) Upadhyay and Panda, 2005; y) Attionu, 1976; z) Ivens, 1989; aa) Chickwenhere, 1994; bb) Chikwenhere, 2001; cc) Cardwell et al., 2002; dd) Moreira et al., 1999; ee) Susarla et al., 1999; ff) Turgut and Fomin, 2002; gg) Teles and Silva, 1974; hh) Cilliers, 1999; ii) Cilliers, 1991; jj) Bowmaker, 1976; kk) Greenway and Woolley, 1999; ll) Marshall and Junor, 1981; mm) Mitchell et al., 1980. 
the highest rate of nutrient uptake, causes significant reductions in dissolved oxygen, and has a high water transpiration rate (Lallana et al., 1987) (which leads to a decreased dilution effect). This species is not yet entirely under any form of control (Coetzee et al. 2011) in South Africa and is likely to continue to have significant impacts on water quality.

\section{Discussion}

In general, South Africa is a water-scarce country and almost all of its accessible freshwater has already been allocated for use (of which agriculture, industry and mining are the largest users) (DWA, 2010). The shortage of available water is exacerbated by water quality problems at a national scale. These include unacceptably high nutrient concentrations at $71 \%$ of the country's monitoring sites, as well as $30 \%$ of monitoring sites having unacceptably high levels of salinisation (DWA, 2011). Situations such as these are caused by poorly functioning wastewater treatment works, run-off from unserviced areas, agricultural runoff, industrial wastewater discharges and mining impacts (Scott, 1995; Burger and Nel, 2008; DWA, 2011). Against this backdrop of a looming water quality crisis and the growing scarcity of water, the water quality impacts of alien invasive plants are likely to be minor. Nonetheless, they worsen an already dire situation; in addition, eutrophication promotes invasion by aquatic weeds, initiating a downward spiral of invasion and decreasing water quality.

Aquatic weeds have flourished in certain South African water resources which have been nutrient enriched by ineffective municipal treatment plants and sewage effluent (Van Ginkel, 2011). In these areas alien invasive plants may result in further deterioration and exceedance of fitness-for-use thresholds. Aquatic weed invasions in Lakes Kariba and Victoria (Ashton and Mitchell, 1989; Hill, 1999b) are examples where waters were being enriched with nutrients by sewage pollution, which created ideal conditions for the spread of water hyacinth and Kariba weed. These infestations further reduced the water quality, inhibited water transport and became a breeding ground for waterborne pathogens. A good example of the impact of invading plant biomass-related impacts on water quality is the invasion of the Western Cape fynbos by Acacia saligna, which increased nitrate and nitrite concentrations beyond acceptable water quality thresholds (DWAF, 1993; Jovanovic et al., 2009). Furthermore, the impacts of allellopathy, recorded in species such as Lantana camara, and species of Prosopis and Eucalyptus, on water quality have not been adequately investigated. It is conceivable that the phenolcontaining terrestrial litter of Eucalyptus species could affect water quality in terms of acidity, organic matter accumulation and nitrification processes, but this has not yet been substantiated by quantitative data. The implications of alien invasive leaf litter decomposition, from species such as Eucalyptus and Quercus, on nutrient dynamics, and the subsequent impacts on water quality, are also yet to be determined.

The impacts of invasive alien plants on water quality, while not considered to be as important as those on water quantity, should also be addressed, particularly in areas where the impacts may worsen already serious water quality problems. This review provides a starting point for the identification of some of these impacts, but it is clear that much research still needs to be carried out if a defensible assessment of the magnitude of the problem is to be made. In the interim, and with some exceptions in limited areas, it is likely that the priorities for clearing invasive alien plants will be dictated by their impacts on water quantity, both in terms of streamflow discharge and groundwater recharge. Prioritised impacts not reflecting on water quantity effects include areas with high levels of erosion following severe fires in invaded stands in fynbos, nitrogen pollution problems in aquifers where nitrogen-fixing Acacia species have invaded, and water bodies (particularly impoundments) where aquatic weeds have become dominant.

\section{Acknowledgements}

We thank the Working for Water programme for funding this review, and Dr H. Malan for useful comments on an earlier draft.

\section{References}

ADAMS S, STRAIN BR and ADAMS MS (1970) Water-repellent soils, fire and annual plant cover in a desert scrub community of Southeastern California. Ecology 51 (4) 696-700.

AERTS R (1997) Climate, leaf litter chemistry and leaf litter decomposition in terrestrial ecosystems: a triangular relationship. Oikos 79 439-449.

AL-NAIB FAG and AL-MOUSAWI AH (1976) Allelopathic effects of Eucalyptus microtheca. Identification and characterization on the phenolic compounds in Eucalyptus microtheca. Kuwait J. Sci. Eng. 3 83-87.

ASHTON PJ (1992) Azolla infestations in South Africa: history of the introduction, scope of the problem and prospects for management. Water Quality Information Sheet. Department of Water Affairs and Forestry, Pretoria, South Africa. 7 pp.

ASHTON PJ (1974) The effect of some environmental factors on the growth of Azolla filiculoides Lam. In: Van Zinderen Bakker Snr EM (ed.) The Orange River-Progress Report. Institute for Environmental Sciences, University of the Orange Free State, Bloemfontein. 123-138.

ASHTON PJ (1977) Factors affecting the growth and development of Azolla filiculoides Lam. In: Annecke DP (ed.) Proc. Second National Weeds Conference of South Africa. A.A. Balkema, Cape Town. 249-268.

ASHTON PJ and MITCHELL DS (1989) Aquatic plants: patterns and modes of invasion, attributes of invading species and assessment of control programmes. In: Drake JA, Mooney HA, Di Castri F, Groves RH, Kruger FJ, Rejmánek M and Williamson M (eds.) Biological Invasions: A Global Perspective. SCOPE Volume 37. John Wiley \& Sons, New York. 111-154.

ASHTON PJ, SCOTT WE, STEYN DJ and WELLS RD (1979) The chemical control programme against the water hyacinth Eichhornia crassipes (Mart.) Solms on Hartbeespoort Dam: Historical and practical aspects. S. Afr. J. Sci. 75 303-306.

ATTIONU RH (1976) Some effects of water lettuce (Pistia stratiotes, L.) on its habitat. Hydrobiologia 50 (3) 245-254.

AWAD AA (2002) Introduced marine species across southern Africa. In: Macdonald IAW, Reaser JK, Bright C, Neville LE, Howard GE, Murphy SJ and Preston G (eds.) Invasive Alien Species in Southern Africa - National Reports and Directory of Resources. Global Invasive Species Programme, Cape Town. 86-90.

BARIK SK, MISHRA S and AYYAPPAN S (2000) Decomposition patterns of unprocessed and processed lignocellulosics in a freshwater fish pond. Aquat. Ecol. 34 (2) 185-200.

BAYLEY SE and SCHINDLER DW (1991) The role of fire in determining stream water chemistry in norther coniferous forests. Chapter 8. In: Mooney HA, Medina E, Schindler DW, Schulze ED and Walker BH (eds.) Ecosystem Experiments. John Wiley \& Sons, New York.

BHARAT YD, RAWAT YS and SINGH SP (1994) Changes in ecosystem functioning after replacement of forest by Lantana shrubland in Kumaun Himalaya. J. Veg. Sci. 5 (1) 67-70.

BOWMAKER AP (1976) The physico-chemical limnology of the Mwenda River mouth, Lake Kariba. Archiv für Hydrobiol. 77 (1) 66-108. 
BRAIMAH H and TIMBILLA JA (1991) Studies towards the effective control of the Siam weed Chromolaena odorata in Ghana. In: Ndoye M (ed.) Exotic Pests in Africa: Prevention and Control. Proc. Ninth Symposium and Scientific Conference of the African Association of Insect Scientists, 23-27 September 1991, Durban, South Africa. 67-71.

BRENDONCK L, MAES J, ROMMENS W, DEKEZA N, NHIWATIWA T, BARSON M, CALLEBAUT V, PHIRI, C, MOREAU K, GRATWICKE B, STEVENS M, ALYN N, HOLSTERS E, OLLEVIER F and MARSHALL BE (2003) The impact of water hyacinth (Eichhornia crassipes) in a eutrophic subtropical impoundment (Lake Chivero, Zimbabwe). II. Species diversity. Archiv für Hydrobiol. 158 (3) 389-405.

BRIGHT C (1998) Life out of Bounds. Biological Invasion in a Borderless World. The Worldwatch Environment Alert Series. W.W. Norton \& Company, New York.

BRITTON DL, DAY JA and HENSHALL-HOWARD M-P (1993) Hydrochemical response during storm events in a South African mountain catchment: the influence of antecedent conditions. Hydrobiologia 250 (3) 143-157.

BROOKS, ML, D'ANTONIO CM, RICHARDSON DM, GRACE JB KEELEY JE, DITOMASO JM, HOBBS RJ, PELLANT M and PYKE D (2004) Effects of invasive alien plants on fire regimes. BioScience 54 (7) 677-688.

BURGER AEC and NEL A (2008) Scoping Study to Determine the Potential Impact of Agricultural Chemical Substances (Pesticides) with Endocrine Disruptor Properties on the Water Resources of South Africa. WRC Report No. 1774/1/08. Water Research Commission, Pretoria.

BURKART A (1976) A monograph of the genus Prosopis (Leguminosae subfamily Mimosoideae): Catalogue of the recognised species of Prosopis. J. Arnold Arbor. 57 (4) 450-525.

CALDER I and DYE P (2001) Hydrological impacts of invasive alien plants. Land Use Water Resour. Res. 1 (7) 1-8.

CARDWELL AJ, HAWKER DW and GREENWAY M (2002) Metal accumulation in aquatic macrophytes from southeast Queensland, Australia. Chemosphere 48 (7) 653-663.

CHAPUIS-LARDY L, CONTOUR-ANSEL D and BERNHARDREVERSAT F (2002) High-performance liquid chromatography of water-soluble phenolics in leaf litter of three Eucalyptus hybrids (Congo). Plant Sci. 163 (2) 217-222.

CHIKWENHERE GP (2001) Current strategies for the management of water hyacinth on the Manyame River system in Zimbabwe. In: Julien MH, Hill MP, Center TD and Ding jian Q (eds.) Biological and Integrated Control of Water Hyacinth, Eichhornia crassipes. Proc. Second Global Working Group Meeting for the Biological and Integrated Control of Water Hyacinth. ACIAR Proceedings No. 102. 105-108.

CHIKWENHERE GP and PHIRI G (1999) History of water hyacinth and its control efforts on Lake Chivero in Zimbabwe. In: Hill MP, Julien MH and Center TD (eds.) Proc. First IOBC Global Working Group Meeting for the Biological and Integrated Control of Water Hyacinth. Weeds Research Division, Agricultural Research Council, South Africa. ARC, Pretoria. 182 pp.

CILLIERS CJ (1991) Biological control of water hyacinth, Eichhornia crassipes (Pontederiaceae), in South Africa. Agric. Ecosyst. Environ. 37 (1-3) 207-217.

CILLIERS CJ (1999b) Biological control of Parrot's feather, Myriophyllum aquaticum (Vell) Verdc. (Haloragaceae), in South Africa. In: Olckers T, Hill MP (eds.) Biological Control of Weeds in South Africa (1990-1998). Afr. Entomol. Mem. 1 113-118.

COETZEE JA, HILL MP, BYRNE MJ and BOWNES A (2011) A review of the biological control programmes on Eichhornia crassipes (C.Mart.) Solms (Pontederiaceae), Salvinia molesta D.S.Mitch. (Salviniaceae), Pistia stratiotes L. (Araceae), Myriophyllum aquaticum (Vell.) Verdc. (Haloragaceae) and Azolla filiculoides Lam. (Azollaceae) in South Africa. Afr. Entomol. 19 (2) 451-468

COGELS FX, COLY A and NIANG A (1997) Impact of dam construction on the hydrological regime and quality of a Sahelian lake in the River Senegal basin. Regul. Rivers: Res. Manage. 13 (1) 27-41.
COUTO L and BETTERS DR (1995) Short-rotation eucalypt plantations in Brazil: Social and Environmental issues. Oak Ridge National Laboratory, Oak Ridge, Tennessee. URL: http://www. osti.gov/energycitations/servlets/purl/36587-6z4lo1/webviewable/36587.PDF (Accessed November 2011).

COX PA, BANACK SA and MURCH SJ (2003) Biomagnification of cyanobacterial neurotoxins and neurodegenerative disease among the Chamorro people of Guam. Proc. Natl. Acad. Sci. USA 100 (23) 13380-13383.

COX PA, BANACK SA, MURCH SJ, RASMUSSEN U, TIEN G, BIDIGARE RR, METCALF JS, MORRISON L F, CODD GA and BERGMAN B (2005) Diverse taxa of cyanobacteria produce $\beta$ - $N$-methylamino-L-alanine, a neurotoxic amino acid. Proc. Natl. Acad. Sci. USA 102 (14) 5074-5078.

CROUCH RL, TIMMENGA HJ, BARBER TR and FUCHSMAN PC (2006) Post-fire surface water quality: Comparison of fire retardant versus wildfire-related effects. Chemosphere 62 (6) 874-889.

CULLIS JDS, GöRGENS AHM and MARAIS C (2007) A strategic study of the impact of invasive alien plants in the high rainfall catchments and riparian zones of South Africa on total surface water yield. Water $S A 33$ (1) 35-42.

DALLAS HF and DAY JA (2004) The Effect of Water Quality Variables on Aquatic Ecosystems: A Review. WRC Report No. TT 224/04. Water Research Commission, Pretoria.

DE GROOT PJ (1993) Introduction and summary. In: Greathead A and De Groot PJ (eds.) Control of Africa's Floating Water Weeds. Commonwealth Science Council, Series no. CSC (93) AGR-18, Proceedings 295. Commonwealth Science Council, Zimbabwe. $187 \mathrm{pp}$.

DE LANGE WJ and VAN WILGEN BW (2010) An economic assessment of the contribution of weed biological control to the management of invasive alien plants and to the protection of ecosystem services in South Africa. Biol. Invasions 12 (12) 4113-4124.

DE RONDE C (1984) Litter accumulation problems identified in Pinus pinaster stands of the Cape Province. S. Afr. For. J. 131 (1) 48-52.

DE WET LPD, SCHOONBEE HJ, PRETORIUS J and BEZUIDENHOUT LM (1990) Bioaccumulation of selected heavy metals by the water fern, Azolla filiculoides Lam. in a wetland ecosystem affected by sewage, mine and industrial pollution. Water $S A 16$ (4) 281-286.

DeBANO LF (1981) Water repellent soils: A state-of-the-art. USDA Forest Service General Technical Report PS W-46, 1-21.

DeBANO LF and CONRAD CE (1976) Nutrients lost in debris and runoff water from a burned chaparral watershed. In: Proc. Third Federal Inter-Agency Sedimentation Conference, Denver, Colorado. Water Resource Council, Washington DC. 13-27.

DWA (DEPARTMENT OF WATER AFFAIRS, SOUTH AFRICA) (2010) Integrated Water Resource Planning for South Africa. DWA Report No. P RSA 000/00/12910. Department of Water Affairs, Pretoria, South Africa.

DWA (DEPARTMENT OF WATER AFFAIRS, SOUTH AFRICA) (2011) Directorate Water Resource Planning Systems: Water Quality Planning. Resource Directed Management of Water Quality. Planning Level Review of Water Quality in South Africa. Sub-Series No.WQP 2.0. Department of Water Affairs, Pretoria, South Africa.

DWAF (DEPARTMENT OF WATER AFFAIRS AND FORESTRY, SOUTH AFRICA) (1993) South African Water Quality Guidelines. Volume 1 -Domestic use ( $1^{\text {st }}$ edn.). Department of Water Affairs and Forestry, Pretoria, South Africa.

DWAF (DEPARTMENT OF WATER AFFAIRS AND FORESTRY, SOUTH AFRICA) (1996) South African Water Quality Guidelines. Volume 1 -Domestic use ( $2^{\text {nd }}$ edn.). Department of Water Affairs and Forestry, Pretoria, South Africa.

DWAF (DEPARTMENT OF WATER AFFAIRS AND FORESTRY, SOUTH AFRICA) (1996b). South African Water Quality Guidelines. Volume 7 -Aquatic Ecosystems. Department of Water Affairs and Forestry, Pretoria, South Africa.

DOERR SH, SHAKESBY RA and MACDONALD LH (2011) Soil water repellency: A key factor in post-fire erosion? In: Cerda A and Robichaud P (eds.) Restoration Strategies after Forest Fires. Science Publishers, Inc., Enfield, NH. 
DURYEA ML, ENGLISH RJ and HERMANSEN LA (1999) A comparison of landscape mulches: chemical, allelopathic, and decomposition properties. J. Arboric. 25 (2) 88-96.

DYE PJ (1996) Climate, forest and streamflow relationships in South African afforested catchments. Commonw. For. Rev. 75 (1) 31-38.

DYE PJ and JARMAIN C (2004) Water use by black wattle (Acacia mearnsii): Implications for the links between removal of invading trees and catchment stream flow response. S. Afr. J. Sci. 100 (1-2) 40-44.

DYE PJ and POULTER AG (1995) Field demonstrations of the effect on streamflow of clearing invasive pine and wattles trees from a riparian zone. S. Afr. For. J. 173 (1) 27-30.

EHRENFELD JG (2003) Effects of exotic plant invasions on soil nutrient cycling processes. Ecosystems 6 (6) 503-523.

ENRIGHT WD (2000) The effect of terrestrial invasive alien plants on water scarcity in South Africa. Phys. Chem. Earth B 25 (3) 237-242.

EUSTON BROWN D (2000) The influence of vegetation type and fire severity on catchment stability after fire: a case study from the Cape Peninsula, South Africa. Unpublished Report, Working for Water Programme, Cape Town. URL: http://intertest.dwa.gov.za/ wfw/docs/Euston-Brown, 2000.pdf (Accessed November 2011).

FELLER MC (1983) Effects of an exotic conifer (Pinus radiata) plantation on forest nutrient cycling in southeastern Australia. For. Ecol. Manage. 7 (2) 77-102.

GALLAHER B, KOCH R and MULLEN K (2002) Quality of Storm Water Runoff at Los Alamos National Laboratory in 2000 with Emphasis on the Impact of the Cerro Grande Fire. Los Alamos National Laboratory LA-13926. URL: http://www.lanl.gov/environment/all/docs/cgf/LA-13926.pdf (Accessed November 2011).

GÖRGENS AHM and VAN WILGEN BW (2004) Invasive alien plants and water resources: an assessment of current understanding, predictive ability and research challenges. S. Afr. J. Sci. 100 (1-2) 27-34.

GRABOW WOK (1996) Waterborne diseases: Update on water quality assessment and control. Water SA 22 (2) 193-20.

GRATWICKE B and MARSHALL BE (2001) The impact of Azolla filiculoides Lam. on animal biodiversity in streams in Zimbabwe. Afr. J. Ecol. 38 (2) 1-4.

GREENWAY M and WOOLLEY A (1999) Constructed wetlands in Queensland - performance efficiency and nutrient bioaccumulation. Ecol. Eng. 12 (1-2) 39-55.

HILL MP and OLCKERS T (2001) Preliminary Assessment of the Social, Economic and Environmental Impacts of Water Hyacinth in the Lake Victoria Basin and the Status of Control. In: Hill MP, Julien MH, Center TD, Jianquing D (eds.) Biological and Integrated Control of Water Hyacinth, Eichhornia crassipes. Proc. Second Global Working Group Meeting for the Biological and Integrated Control of Water Hyacinth. ACIAR Proceedings No. 102. ACIAR, Canberra.

HILL MP (1999) The world's worst aquatic weed. Pestic. Outlook 10 (2) $58-62$.

HILL MP (2003) The impact and control of alien aquatic vegetation in South African aquatic ecosystems. Afr. J. Aquat. Sci. 28 (1) 19-24.

HOLMES PM, RICHARDSON DM, VAN WILGEN BW and GELDERBLOM C (2000) Recovery of South African fynbos vegetation following alien woody plant clearing and fire: implications for restoration. Austral Ecol. 25 (6) 631-639.

HUSSNER A (2010) NOBANIS - Invasive Alien Species Fact Sheet - Azolla filiculoides. Online Database of the North European and Baltic Network on Invasive Alien Species - NOBANIS. URL: www.nobanis.org (Accessed 23 February 2011).

IVENS GW (1989) East African Weeds and Their Control (2 ${ }^{\text {nd }}$ edn.). Oxford University Press, Nairobi.

JADHAV A, HILL MP and BYRNE M (2008) Identification of a retardant dose of glyphosate with potential for integrated control of water hyacinth, Eichhornia crassipes (Mart.) Solms-Laubach. Biol. Control 47 (2) 154-158.

JAYIYA TP, MOSES G, FORSYTH GG and VAN WILGEN BW (2004) The effects of invasion by alien shrubs and trees on the fuel properties of ecosystems in the Western Cape, South Africa. CSIR report to Working for Water. URL: http:/www.dwaf.gov.za/wfw/
docs/Jayiyaetal.,2004.pdf (Accessed November 2011).

JONES RW (2001) Integrated Control of Water Hyacinth on the Nseleni/Mposa Rivers and Lake Nsezi, Kwa Zulu-Natal, South Africa. In: Julien MH, Hill MP, Center TD and Jianqing D (eds.) Biological and Integrated Control of Water Hyacinth, Eichhornia crassipes. Proc. Second Global Working Group Meeting for the Biological and Integrated Control of Water Hyacinth. ACIAR Proceedings No. 102. ACIAR, Canberra.

JOVANOVIC NZ, ISRAEL S, TREDOUX G, SOLTAU L, LE MAITRE D, RUSINGA F, ROZANOV A and VAN DER MERWE $\mathrm{N}$ (2009) Nitrogen dynamics in land cleared of alien vegetation (Acacia saligna) and impacts on groundwater at Riverlands Nature Reserve (Western Cape, South Africa). Water SA 35 (1) 37-44.

KALFF J (2002) Limnology: Inland Water Systems. Prentice Hall, Upper Saddle River, NJ.

KEELEY JE (2009) Fire intensity, fire severity and burn severity: a brief review and suggested usage. Int. J. Wildland Fire 18 (1) $116-126$.

KELBE B and GERMISHUYSE T (1999) A study of the relationship between hydrological processes and water quality characteristics in the Zululand coastal region. WRC Report No. 346/1/99. Water Research Commission, Pretoria

KHEDR AHA (1997) Distribution of aquatic plants in relation to environmental factors in the Nile Delta. Aquat. Bot. 56 (1) 75-86.

KONING N, ROOS JC and GOBBELAAR JU (2000) Water quality of the Modder River, South Africa. Afr. J. Aquat. Sci. 25 (1) 202-210.

LALLANA VH, SABATTINI RA and LALLANA MDC (1987) Evapotranspiration from Eichhornia crassipes, Pistia stratioides, Salvinia herzogii and Azolla caroliniana during summer in Argentina. J. Aquat. Plant Manage. 25 48-50.

LANE PNJ, SHERIDAN GJ and NOSKE PJ (2006) Changes in sediment loads and discharge from small mountain catchments following wildfire in south eastern Australia. J. Hydrol. 331 (3-4) 495-510.

LE MAITRE DC, VAN WILGEN BW, CHAPMAN RA and McKELLY DH (1996) Invasive plants and water resources in the Western Cape Province, South Africa: Modelling the consequences of a lack of management. J. Appl. Ecol. 33 (1) 161-172.

LE MAITRE DC, VERSFELD, DB and CHAPMAN RA (2000) The impact of invading alien plants on surface water resources in South Africa: a preliminary assessment. Water SA 26 (3) 397-408.

LEE GF (1973) Role of phosphorus in eutrophication and diffuse source control. Water Res. 7 (1-2) 111-128.

LINDEMANN WC and GLOVER CR (2003) Nitrogen Fixation by Legumes. Guide A-129. Cooperative Extension Service, College of Agriculture and Home Economics, New Mexico State University, Las Cruces.

MACDONALD IAW (1983) Alien trees, shrubs and creepers invading indigenous vegetation in the Hluhluwe-Umfolozi Game Reserve complex in Natal. Bothalia 14 (3-4) 949-959.

MAILU AM (2001) Preliminary assessment of the social, economic and environmental impacts of water hyacinth in the Lake Victoria Basin and the status of control. In: Hill MP, Julien MH, Center TD and Jianquing D (eds.) Biological and Integrated Control of Water Hyacinth, Eichhornia crassipes. Proc. Second Global Working Group Meeting for the Biological and Integrated Control of Water Hyacinth. ACIAR Proceedings No. 102. ACIAR, Canberra.

MALAN H (2011) Personal communication, 30 April 2011. Dr Heather Malan, Freshwater Research Unit, University of Cape Town, Private Bag, Rondebosch 7701, South Africa.

MALAN H, BATH A, DAY JA and JOUBERT A (2003) A simple flow-concentration modelling method for integrating water quality and water quantity in rivers. Water SA 29 (3) 305-311.

MALAN HL and DAY JA (2002) Linking Discharge, Water Quality and Biotic Response in Rivers: a Literature Review. WRC Report No. 956/2/02. Water Research Commission, Pretoria.

MALAN HL and DAY JA (2003a) Linking flow, water quality and potential effects on aquatic biota within the Reserve determination process. Water SA 29 (3) 297-304.

MALAN HL and DAY JA (2003b) Predicting Water Quality and Biotic Response in Ecological Reserve Determinations. WRC Report No. TT202/02. Water Research Commission, Pretoria. 
MALLYA GA (1999) Water hyacinth in Tanzania. In: Hill MP, Julien $\mathrm{MH}$ and Center TD (eds.) Proc. First IOBC Global Working Group Meeting for the Biological and Integrated Control of Water Hyacinth. Weeds Research Division, Agricultural Research Council, Pretoria, South Africa. $182 \mathrm{pp}$

MARSHALL BE and JUNOR FJR (1981) The decline of Salvinia molesta on Lake Kariba. Hydrobiologia 83 (3) 477-484.

MASIFWA WF, TWONGO T and DENNY P (2001) The impact of water hyacinth, Eichhornia crassipes (Mart) Solms on the abundance and diversity of aquatic macroinvertebrates along the shores of northern Lake Victoria, Uganda. Hydrobiologia 452 (1-3) 79-88.

McNEIL AM and UNKOVICH MJ (2007) The nitrogen cycle in terrestrial ecosystems. In: Marschner P and Rengel Z (eds.) Nutrient Cycling in Terrestrial Ecosystems. Soil Biology, Vol 10. SpringerVerlag, Amsterdam. 37-64.

MILTON SJ (2004) Grasses as invasive alien plants in South Africa. S. Afr. J. Sci. 100 (1-2) 69-75.

MISHRA VK and TRIPATHIA BD (2008) Concurrent removal and accumulation of heavy metals by the three aquatic macrophytes. Bioresour. Technol. 99 (15) 7091-7097.

MITCHELL DS, PETR T and VILNER AB (1980) The water-fern Salvinia molesta in the Sepik River, Papua New Guinea. Environ. Conserv. 7 (2) 115-122.

MOODY JA and MARTIN DA (2009) Synthesis of sediment yields after wildland fire in different rainfall regimes in the western United States. Int. J. Wildland Fire 18 (1) 96-115.

MORAN C, HOFFMAN JH, DONNELLY D, VAN WILGEN BW and ZIMMERMAN HG (2000) Biological control of alien, invasive pine trees (Pinus species) in South Africa. In: Spencer NR (ed.) Proc. Xth International Symposium on Biological Control of Weeds, 4-14 July 1999, Montana State University, Bozeman, Montana, USA. 941-953.

MOREIRA I, MONTEIRA A and FERREIRA T (1999) Biology and control of Parrotfeather (Myriophyllum aquaticum) in Portugal. Ecol. Environ. Conserv. 5 (3) 171-179.

MORRIS AR (1995) Forest floor accumulation, nutrition and productivity of Pinus patula in the Usutu Forest, Swaziland. Plant Soil 168-169 (1) 271-278.

MUSIL CF (1993) Effect of invasive Australian acacias on the regeneration, growth and nutrient chemistry of South African lowland fynbos. J. Appl. Ecol. 30 (2) 361-372.

MUSIL CF and MIDGLEY GF (1990) The relative impact of invasive Australian acacias, fire and season on the soil chemical status of a sand plain lowland fynbos community. S. Afr. J. Bot. 56 (4) 419-427.

NAGLER PL, GLENN EP, DIDAN K, OSTERBERG J, JORDON F and CUNNINGHAM J (2008) Wide-area estimates of stand structure and water use of Tamarix spp. on the lower Colorado River: Implications for restoration and water management projects. Restor. Ecol. 16 (1) 136-145.

OKEDI JY (1990) Observations on the benthos of Murchison Bay, Lake Victoria, East Africa. Afr. J. Ecol. 28 (2) 111-122.

OLIVER JD (1993) A review of the biology of giant salvinia (Salvinia molesta Mitchell). J. Aquat. Plant Manage. 31 227-231.

OOSTUIZEN GJ and WALTERS MM (1961) Control of water fern with diesoline. Farming S. Afr. 37 35-37.

PALM CA, GACHENCO CN, DELVE RJ, CADISCH G and GILLER KE (2001) Organic inputs for soil fertility management in tropical agroecosystems: Application of an organic resource database. Agric. Ecosyst. Environ. 83 (1-2) 27-42.

PAMMENTER NW, BERJAK M and MACDONALD IAW (1985) Regeneration of a Natal coastal dune forest after fire. S. Afr. J. Bot. 51 (6) 453-459.

PETTICREW EL, OWENS PN and GILES TR (2006) Wildfire effects on the quantity and composition of suspended and gravel-stored sediments. Water Air Soil Pollut. Focus 6 (5-6) 647-656.

PIETERSE AH and MURPHY KJ (1989) Aquatic Weeds: The Ecology and Management of Nuisance Aquatic Vegetation. Oxford University Press, New York.

POLOMSKI RF, TAYLOR MD, BIELENBERG DG, BRIDGES WC, KLAINE SJ and WHITWELL T (2009) Nitrogen and phosphorus remediation by three floating aquatic macrophytes in greenhouse-based laboratory-scale subsurface constructed wetlands. Water Air Soil Pollut. 197 (1-4) 223-232.

POZO J, BASAGUREN A, EL'OSEGUI A, MOLINERO J, FABRE E and CHAUVET E (1998) Afforestation with Eucalyptus globulus and leaf litter decomposition in streams of northern Spain. Hydrobiologia 373/374 (0) 101-109.

PRINSLOO FW and SCOTT DF (1999) Streamflow responses to the clearing of alien invasive trees from riparian zones at three sites in the Western Cape Province. S. Afr. For. J. 185 (1) 1-7.

RAID N and MUNSHI J D (1979) The influence of thick floating vegetation (water hyacinth: Eichhornia crassipes) on the physico -chemical environment of a fresh water wetland. Hydrobiologia 62 (1) 65-69.

RAINS DW and TALLEY SN (1979) Nitrogen and Rice. International Research Institute, Los Banos, Laguna, Philippines. 419-435.

RAMAKRISHNAN PS (1992) Shifting agriculture and sustainable development - an interdisciplinary study from North-Eastern India. Man and the Biosphere Series Vol. 10. UNESCO and The Parthenon Publishing Group, Paris. 424 pp.

RAUBENHEIMER CM and DAY JA (1991) In vitro leaching of two sclerophyllous fynbos plants. Hydrobiologia 224 (3) 167-174.

RENEAU SL, KATZMAN D, KUYUMJIAN GA, LAVINE A and MALMON DV (2007) Sediment delivery after a wildfire. Geology 35 (2) $151-154$

RICHARDSON DM and VAN WILGEN BW (1986) The effects of fire in felled Hakea sericea and natural fynbos and the implications for weed control in mountain catchments. S. Afr. For. J. 139 (1) 414

RICHARDSON DM and VAN WILGEN BW (2004) Invasive alien plants in South Africa: How well do we understand the ecological impacts? S. Afr. J. Sci. 100 (1) 45-52.

RICHARDSON DM, MACDONALD, IAW, HOFFMANN JH and HENDERSON L (1997) Alien plant invasions. In: Cowling RM, Richardson DM and Pierce SM (eds.) Vegetation of Southern Africa. Cambridge University Press, Cambridge. 535-570.

ROSSOUW JN (2004) Water quality in the ecological reserve for river ecosystems. Proc. Water Institute of Southern Africa (WISA) Biennial Conference, 2-6 May 2004, Cape Town, South Africa.

ROURA-PASCUAL N, RICHARDSON DM, KRUG R, BROWN A, CHAPMAN RA, FORSYTH GG, LE MAITRE DC, ROBERTSON MP, STAFFORD L, VAN WILGEN BW and WESSELS N (2009) Ecology and management of alien plant invasions in South African fynbos: accommodating key complexities in objective decisionmaking. Biol. Conserv. 142 (8) 1595-1604.

SCOTT DF (1993) The hydrological effects of fire in South African mountain catchments. J. Hydrol. 150 (2-4) 409-432.

SCOTT DF (1999) Managing riparian zone vegetation to sustain streamflow: results of paired catchment experiments in South Africa. Can. J. For. Res. 29 (7) 1149-1157.

SCOTT DF and SCHULZE RE (1992) The hydrological effects of a wildfire in a eucalypt afforested catchment. S. Afr. For. J. 160 (1) $67-74$

SCOTT DF and VAN WYK DB (1990) The effects of wildfire on soil wettability and hydrological behaviour of an afforested catchment. J. Hydrol. 121 (1-4) 239-256.

SCOTT DF, VERSFELD DB and LESCH W (1998) Erosion and sediment yields in relation to afforestation and fire in the mountains of the Western Cape Province, South Africa. S. Afr. Geogr. J. 80 (1) $52-59$.

SCOTT R (1995) Flooding of Central and Grand Rand Gold Mines: an investigation into controls over the inflow rate, water quality and the predicted impacts of flooded mines. WRC Report No. 486/1/95. Water Research Commission, Pretoria. 238 pp.

SCOTT WE, ASHTON PJ and STEYN DJ (1979) Chemical Control of the Water Hyacinth on Hartbeespoort Dam. CSIR Special Report WAT M20. CSIR, Pretoria.

SHEEJA BD (1993) Allelopathic effects of Eupatorium odoratum L. and Lantana camara L. on four major crops. M. Phil. Dissertation, Manonmaniam Sundaranar University, Tirunelveli.

SHERIDAN G, LANE P, NOSKE P, FEIKEMA P, SHERWIN C and GRAYSON R (2007) Impact of the 2003 Alpine Bushfires on Streamflow: Estimated Changes in Stream Exports of Sediment, Phosphorus and Nitrogen following the 2003 Bushfires in Eastern 
Victoria. Murray-Darling Basin Commission, MDBC Publication No. 22/08. MCBC, Canberra.

SKOROSZEWSKI R (1999) Specialist Report: Water quality. Lesotho Highlands Development Authority Report no. LHDA 648-F-15. Metsi Consultants/ Southern Waters Ecological Research and Consulting, Freshwater Research Unit, University of Cape Town.

SMITH HG, SHERIDAN GJ, LANE PNJ, SNYMAN P and HAYDON S (2011) Wildfire effects on water quality in forest catchments: A review with implications for water supply. J. Hydrol. 396 (1-2) 170-192.

SPIRA WM, HUQ A, AHMED QS and SAEED YA (1981) Uptake of Vibrio cholerae biotype eltor from contaminated water by water hyacinth (Eichhornia crassipes). Appl. Environ. Microbiol. 42 550-553.

SRIDHAR MKC and SHARMA BM (1980) Pistia stratiotes L. in Nigerian waters. Experientia 36 (8) 953-955.

SRIDHAR MKC and SHARMA BM (1985) Some observations on the oxygen changes in a lake covered with Pistia stratiotes L. Water Res. 19 (7) 935-939.

STEWART BA and DAVIES BR (1990) Allochthonous input and retention in a small mountain stream, South Africa. Hydrobiologia 202 135-146.

STOCK WD, WIENAND KT and BAKER AC (1995) Impacts of invading $\mathrm{N}_{2}$-fixing Acacia species on patterns of nutrient cycling in two Cape ecosystems: evidence from soil incubation studies and ${ }^{15} \mathrm{~N}$ natural abundance values. Oecologia 101 (3) 375-382.

STROMBERG JC (1998) Functional equivalency of saltcedar (Tamarix chinensis) and Fremont cottonwood (Populus fremontii) along a free-flowing river. Wetlands 18 (4) 675-686.

SUSARLA S, BACCHUS ST, WOLFE NL and McCUTCHEON SC (1999) Phytotransformation of perchlorate and identification of metabolic products in Myriophyllum aquaticum. Int. J. Phytorem. 1 (1) $97-107$.

SZCZEŚNIAK E, BÍACHTA J, KRUKOWSKI M and PICIńSKAFAÍTYNOWICZ E (2009) Distribution of Azolla filiculoides Lam. (Azollaceae) in Poland. Acta Societatis Botanicorum Polaniae 78 (3) 241-246.

TELES AN and SILVA ARP (1974) Myriophyllum aquaticum (Vell.) Verdcourt., an aggressive aquatic weed. Agronomica Lusitania 36 307-323.

TéLLEZ TR, DE RODRIGO LóPEZ EM, GRANADO GL, PéREZ EA, LóPEZ RM and GUZMáN JMS (2008) The Water Hyacinth, Eichhornia crassipes: an invasive plant in the Guadiana River Basin (Spain). Aquat. Invasions 3 (1) 42-53.

TOERIEN DF and WALMSLEY RD (1979) The chemical composition of the upper Hennops River and its implications on the water quality of Rietvlei Dam. Water SA 5 (2) 77-89.

TRIPATHI BD, SRIVASTAVA J and MISRA K (1991) Nitrogen and phosphorus removal-capacity of four chosen aquatic macrophytes in tropical freshwater ponds. Environ. Conserv. 18 (2) 143-147.

TURGUT C and FOMIN A (2002) The ability of Myriophyllum aquaticum (Vell.) Verdcourt in the uptake and the translocation of pesticides via roots with a view to using the plants in sediment toxicity testing. J. Appl. Bot. 76 (1-2) 62-65.

TURPIE JK, MARAIS C and BLIGNAUT JN (2008) The working for water programme: Evolution of a payments for ecosystem services mechanism that addresses both poverty and ecosystem service delivery in South Africa. Ecol. Econ. 65 (4) 788-798.

TWONGO T and BALIRWA J (1995) The water hyacinth problems and the biological control option on the Highland Lake Region of the Upper Nile Basin- Uganda's experience. Paper presented at Nile 2000, Conference on Comprehensive Resources Development of the Nile Basin, 13-17 February 1995, Arusha, Tanzania.

UPADHYAY RK and PANDA SK (2005) Salt tolerance of two aquatic macrophytes, Pistia stratiotes and Salvinia molesta. Biologia Plantarum 49 (1) 157-159.

VAN DER WAAL BJ (2009) The influence of Acacia mearnsii invasion on soil properties in the Kouga Mountains, Eastern Cape, South Africa. M.Sc. thesis, Rhodes University, Grahamstown.

VAN GINKEL CE (2011) Eutrophication: Present reality and future challenges for South Africa. Water SA 37 (5) 693-701.
VAN LILL WS, KRUGER FJ and VAN WYK DB (1980) The effect of afforestation with Eucalyptus grandis Hill ex Maiden and Pinus patula Schlecht. Et. Cham. on streamflow from experimental catchments at Mokubalaan, Transvaal. J. Hydrol. 48 (1-2) 107-118.

VAN WILGEN BW and RICHARDSON DM (1985) The effects of alien shrub invasions on vegetation structure and fire behaviour in South African fynbos shrubland: a simulation study. J. Appl. Ecol. 22 (3) 955-966.

VAN WILGEN BW and SCOTT DF (2001) Managing fires on the Cape Peninsula: Dealing with the inevitable. J. Mediterr. Ecol. 2 197-208.

VAN WILGEN BW, KHAN A and MARAIS C (2011) Changing perspectives on managing biological invasions: insights from South Africa and the Working for Water programme. In: Richardson DM (ed.) Fifty Years of Invasion Ecology: The Legacy of Charles Elton. Wiley-Blackwell Publishers, Oxford. 377-393.

VAN WILGEN BW, REYERS B, LE MAITRE DC, RICHARDSON DM and SCHONEGEVEL L (2008) A biome-scale assessment of the impact of invasive alien plants on ecosystem services in South Africa. J. Environ. Manage. 89 (4) 336-349.

VAN WYK DB (1985) The effects of catchment management on sediment and nutrient exports in the Natal Drakensberg. In: Schulze RE (ed.) Proc. 2nd South African National Hydrological Symposium. University of Natal, Pietermaritzburg. 266-274.

VAN WYK DB (1987) Some effects of afforestation on streamflow in the Western Cape Province, South Africa. Water SA 14 (1) 31-36.

VERSFELD DB and DONALD DGM (1991) Litterfall and nutrient release in mature Pinus radiata in the south-western Cape. S. Afr. For. J. 156 (1) 61-69.

VERSFELD DB and VAN WILGEN BW (1986) Impacts of woody aliens on ecosystem properties. In: MacDonald IAW., Kruger FJ and Ferrar AA (eds.) The Ecology and Control of Biological Invasions in South Africa. Oxford University Press, Cape Town. 239-246.

VIRTUE JG and MELLAND RL (2003) The Environmental Weed Risk of Revegetation and Forestry Plants. South Australia. Department of Water, Land and Biodiversity Conservation. Report, DWLBC 2003/02.

WHITE I, WADE A, WORTHY M, MUELLER N, DANIELL T and WASSON R (2006) The vulnerability of water supply catchments to bushfires: impacts of the January 2003 wildfires on the Australian Capital Territory. Aust. J. Water Resour. 10 (2) 1-16.

WILKINSON SN, WALLBRINK PJ, HANCOCK GJ, BLAKE WH, SHAKESBY RA and DOERR SH (2009) Fallout radionuclide tracers identify a switch in sediment sources and transport-limited sediment yield following wildfire in a eucalypt forest. Geomorphology $110(3-4)$ 140-151.

WILLIAMS AE and HECKY RE (2005) Invasive aquatic weeds and eutrophication: The case of water hyacinth in Lake Victoria. In: Reddy MV (ed.) Restoration and Management of Tropical Eutrophic Lakes. Science Publishers, Enfield, NH. 187-225.

WINARSO S, SULISTYANTO D and HANDAYANTA E(2011) Effects of humic compounds and phosphate solubilizing bacteria on phosphorus availability in an acid soil. J. Ecol. Nat. Environ. 3 (7) $232-240$.

WITKOWSKI ETF (1991) Effects of invasive alien acacias on nutrient cycling in the coastal lowlands of the Cape fynbos. J. Appl. Ecol. 28 (1) $1-15$.

WITKOWSKI ETF and MITCHELL DT (1987) Variations in soil phosphorus in the fynbos biome, South Africa. J. Ecol. 75 (4) $1159-1171$.

YELENIK SG, STOCK WD and RICHARDSON DM (2004) Ecosystem level impacts of invasive Acacia saligna in the South African Fynbos. Restor. Ecol. 12 (1) 44-51.

ZACHARIADES C and GOODALL JM (2000) Distribution, impact and management of Chromolaena odorata in Southern Africa. Proc. Fifth International Workshop on Biological Control and Management of Chromolaena odorata, 23-25 October 2000, Durban, South Africa. 